\title{
Some Characteristic Properties of Chestnut and Rhododendron Honeys in Turkey
}

\author{
Türkiye'deki Kestane ve Ormangülü Ballarının \\ Bazı Karakteristik Özellikleri
}

\author{
Research Article
}

Nazlı Mayda' ${ }^{*}$, Aslı Özkök², Kadriye Sorkun ${ }^{1,2}$

'Hacettepe University, Science Faculty, Biology Department, Beytepe, Ankara, Turkey.

${ }^{2}$ Hacettepe University, Bee and Bee Products Applications and Research Center (HARÜM), Beytepe, Ankara, Turkey

\section{A B S T R ACT}

C hestnut (Castanea sativa Mill.) and Rhododendron (Rhododendron spp. L.) (mad honey) honeys are produced generally in Black Sea Region in Turkey and both of them are the special honeys because of their organic component content and known their high antioxidant capacity. In the first step of this study we researched the melissopalynological differentiation of the chestnut and rhododendron honeys and then in the second step we determined the chemical compounds and sugar content of the rhododendron, chestnut and mixed chestnut\&rhododendron honeys. For this purpose total 18 honey samples were collected from 4 different districts from Black Sea Region of Turkey and melissopalynological analyses were done by microscope. Chemical composition and sugar content (fructose\&glucose) were determined by High Performance Liquid Chromatograpy (HPLC) and Gas Chromatography-Mass Spectrometry (GC-MS). After melissopalynological anaylses were obtained 10 monofloral chestnut, 2 monofloral rhododendron and 6 mixed chestnut\&rhododendron honeys. As a result of sugar analysis with HPLC, F/G rates were found between 1.17 and 1.80. GC-MS chemical substance analyses of honeys revealed alcohols, aldehydes, ketones, aliphatic acids and their esters, carboxylic acids and their esters and flavanonoids.

\section{Key Words}

Chestnut honey, rhododendron honey, mellissopalynological analysis, sugar analysis, chemical compounds.

\section{öz}

Türkiye'de genellikle Karadeniz bölgesinde üretilen kestane (Castanea sativa Mill.) ve ormangülü (Rhododendron spp. L.) (delibal) balları içerdiği organik bileşenler ve yüksek antioksidan seviyeleri ile bilinen önemli ballardır.Bu çalışmanın ilk aşamasında kestane ve ormangülü ballarının melissopalinolojik farkıılıkları araştırılmış, ikinci aşamasında ise ormangülü, kestane ve kestane ormangülü karışık balların şeker içerikleri ve kimyasal bileşenleri belirlenmiştir. Bu amaçla Türkiye'nin Karadeniz Bölgesinde, 4 farklı yerden toplamda 18 bal örneği toplanmıştır ve mikroskop ile melissopalinolojik analizleri yapıımıştır. Kimyasal bileşim ve şeker içeriği (fruktoz\&glikoz) HPLC ve GC-MS ile belirlenmiştir. Melissopalinolojik analizler sonrasında 10 balın monofloral kestane balı, 2'sinin monofloral ormangülü ve 6'sının da kestane ormangülü karışık ballar olduğu saptanmıştır. HPLC ile yapılan şeker analizleri sonucunda F/G oranının 1.17 ve 1.80 arasında olduğu, GC-MS kimyasal analizleri sonucunda da balların alkoller, aldehidler, ketonlar, alifatik asit ve esterleri, carboksilik asit ve esterleri ile flavanoidleri içerdiği ortaya çıkarılmıştır.

\section{Anahtar Kelimeler}

Kestane balı, deli bal, melissopalinolojik analizler, şeker analizleri, kimyasal bileşikler.

Article History: Received: Feb 02, 2017; Revised: Feb 08, 2017; Accepted: Feb 09, 2017; Available Online: Feb 21, 2018.

DOI: $10.15671 /$ HJBC.2018.223

Correspondence to: N. Mayda, Department Of Biology, Hacettepe University, Ankara, Turkey. 


\section{INTRODUCTION}

Chestnut (Castanea sativa Mill.) and Rhododendron (Rhododendron spp. L.) (mad honey) honeys are found generally in Black Sea Region in Turkey and both of them are the special honeys for their organic component content and known their high antioxidant activity.

Chesnut plant is one of the best sources of nectar and pollen for honeybees. Chestnut honey with dark color and bitter taste, can stay in a liquid state for a long time because of its slow crystallization rate $[1,2]$.

Mad honey, produced by honeybees from the nectars of Rhododendron genus ( $R$. ponticum and $R$. luteum) flowers. $R$. ponticum and $R$. luteum plants, which are belongs to Ericaceae family, grow mainly in the Black Sea Region of Turkey, Japan, Nepal, Brazil, Europe and some parts of North America [3]. This honey's taste is bitter because of its slightly sharp taste and most of them contains toxins which are called grayanotoxins and they can be toxic when their consumption. So people use generally "Mad Honey" name for this honey due to subsequent consumption effects. On the other hand this honey is widely used in indigenous medicine [2].

In Rhododendron genus, 208 compounds have been isolated, composed of mostly flavonoids and diterpenoids [4]. Most of those diterpenoids are grayane-type diterpenoids, polyhydroxylated cyclic hydrocarbons that do not contain nitrogen [5]. It is reported that mad honey intoxication is largely associated with lipid-soluble grayanotoxins (GTXs) similar to the alkaloids veratridine, acotinine and batrachotoxin [6]. GTXs tend to bind to the activated state of sodium channels and cause persistent activation at resting membrane potential. They lead to blockage of sodium channel inactivation and shift of the voltage dependence of activation to more negative potentials $[2,7]$.

In this study we researched the melissopaynological differentiation of the chestnut and rhododendron honeys and then we determined the chemical compounds and sugar content of the rhododendron, chestnut and mixed chestnut rhododendron honeys

\section{MATERIALS and METHODS}

\section{Collection of Honey Samples}

Honey samples were provided by beekeepers. Total 18 honey samples were collected from 4 different districts [Bartın $(n=10)$; Kastamonu $(n=1)$; İstanbul $(n=1)$; Düzce $(n=6)$ ] from Black Sea Region of Turkey (Figure 1). Pollen analysis was performed to authenticate the botanical origin of chestnut and rhododendron honeys.

\section{Microscopic Analysis of Honeys}

For microscopic analysis Wodehouse (1935) [8] and Sorkun (2008) [9] methods were accepted and honey preparations were examined by Olympus CX41 microscope.

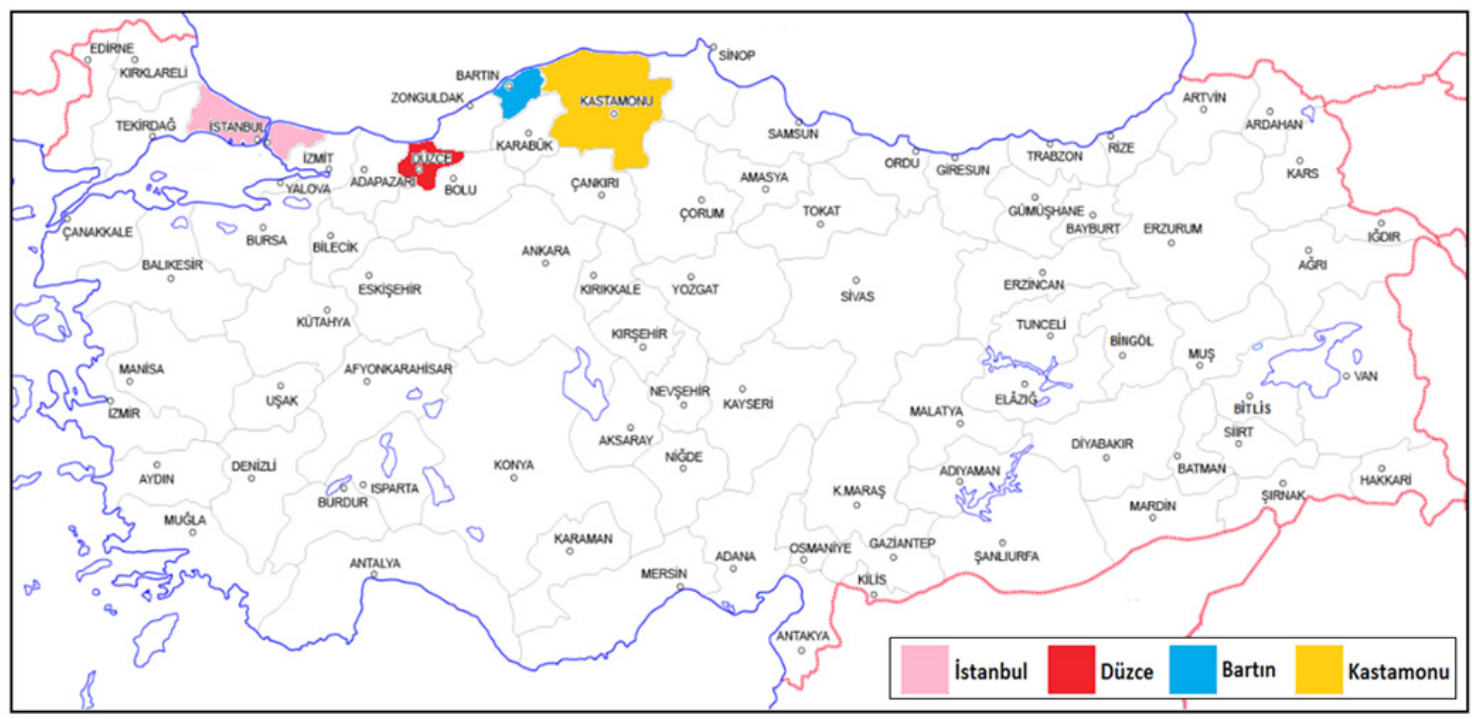

Figure 1. The regions where honey samples were collected. 


\section{Preparates from Honey Samples}

Preparates to identify in 10 grams of honey are obtained as follows:

500 grams of stock honey was well stirred with a sterile glass stick and 10 grams of it was separated for obtain preparats. Then the sample and $20 \mathrm{ml}$ distilled water mixed in a tube and left in a water bath of $45^{\circ} \mathrm{C}$ for $30-45$ minutes. Then this melted honey mixture was centrifuged in $3500 \mathrm{rpm}$ for 45 minutes. Water in centrifuged tubes was removed and tubes were left upside down on a drying mat for full drainage. The material was taken from the bottom of the tube and plated on a lam with basic fucsin-glycerin gelatin mixture.

Basic fucsin-glycerin-gelatine mixture and honey were taken with the edge of a sterile needle was transferred to a microscope slide and put on a hotplate set at $40^{\circ} \mathrm{C}$. When the gelatine was melted, $18 \times 18 \mathrm{~mm}$ cover slips were placed on the samples. Pollen slides were researched with Olympus CX41 microscope and immersion objective (x100) was used for identification of pollens. During microscopic studies all the area, which is $18 \times 18 \mathrm{~mm}$ was checked. 200 pollen was counted for every sample and determined pollen types according to their botanical origin.

Relevant sources were used in the identification of the pollen were from Persano Oddo and Piro (2004) [10], Özkök Tüylü and Sorkun (2007) [11] and Sorkun (2008) [9] as well as reference preparats

\section{Determination of the Botanical Originals of Honey Samples}

The determination of the botanical origin is based on the relative frequencies of nectariferous species' pollen types. The frequency classes of pollen grains were given as predominant $(>45 \%)$, secondary pollen (15-45\%), important minor pollen (3-15\%) and minor pollen («3\%) [12].

GGenerally a honey can be defined as unifloral if the "characteristic" pollen (e.g. Brassica in rape honey) exceeds $45 \%$. These are general guidelines but many pollen types are underrepresented (Robinia pseudoacacia, Citrus spp., Tilia spp.) or overrepresented (Castanea sativa, Eucaliptus spp.). For instance, to characterize acacia honey as unifloral, R. pseudoacacia pollen must be over $15 \%$, citrus must have at least $10 \%$ of Citrus spp. pollen while, for chestnut honey, a content of $70-90 \%$ of Castanea pollen is required to classify honey as unifloral [12-14].

\section{High Performance Liquid Chromatography (HPLC) Sugar Analysis}

Bogdanov and Baumann (1988) [15] method and HPLC (Agilent 1200 Series) were used for the determination of fructose and glucose at honey samples. According to this method $5 \mathrm{~g}$ honey was weighed into a beaker and dissolved in $40 \mathrm{ml}$ water. Pipetted $25 \mathrm{ml}$ of methanol into a $100 \mathrm{ml}$ volumetric flask and transferred the honey solution quantitatively to the flask. Filled to the mark with water. Poured through a membrane filter and collected in sample vials. Also fructose $(2 \mathrm{~g})$ and glucose $(1.5 \mathrm{~g})$ standards were prepared same way. 80 volumes of acetonitrile to 20 volumes of water mix was used as mobil phase. Flow rate was $1.3 \mathrm{ml} /$ min at constant temperature of $30^{\circ} \mathrm{C}$.

\section{Gas Chromatography-Mass Spectrometry (GC-MS) Chemical Compounds Analysis}

GC-MS was used for chemical compound analysis of the honey samples. $5 \mathrm{~g}$ honey dissolved in $5 \mathrm{ml}$ methanol and mixed for 1 minute by vortex. Next centrifuged at 3500 rpm for 15 minutes. Then upper phase was filtered to vials and $1 \mu$ l solution injected to GC-MS. A GC $6890 \mathrm{~N}$ from HewlettPackard (Palo Alto, CA, USA) coupled with mass detector (MS 5973 Hewlett-Packard) was used for the analysis of honey samples. Experimental conditions of GC-MS system were as follows: DB 5MS column (30 mx0.25 mm and $0.25 \mu \mathrm{m}$ of film thickness) was used and flow rate of mobile phase (He) was set at $0.7 \mathrm{ml} / \mathrm{min}$. In the gas chromatography part, temperature was kept at $150^{\circ} \mathrm{C}$ with $10^{\circ} \mathrm{C} /$ min heating ramp. After this period, temperature was kept at $150^{\circ} \mathrm{C}$ for 2 minutes. Finally, temperature was increased to 280 with $20^{\circ} \mathrm{C} / \mathrm{min}$ heating ramp and then kept at $280^{\circ} \mathrm{C}$ for 49 minutes and chemical substances of the honey samples were identified by using standard Nist Libraries available in the data acquisition system of GC-MS.

\section{RESULTS and DISCUSSION}

After melissopalynological anaylsis were obtained 10 monofloral chestnut, 2 monofloral rhododendron and 3 mixed chestnut\&rhododendron honeys (Table 1) (Figure 2 and 3). 
According to Turkish Food Codex (2012) [16] and Codex Alimentarius Committee on Sugars (2001) [17] sum of the fructose and glucose should be not less than $60 \mathrm{~g} / 100 \mathrm{~g}$ and ratio of fructose to glucose should be between $1.0 \%$ and $1.85 \%$ for chestnut honeys. White (1978) [18] reported that the ratio of Fructose and Glucose in honey varied from 1.0 to 1.2 and this ratio could also change depending on the nutrition the beekeper has made during the spring. Manzanares et al. (2017) [19] with 42 chestnut honeys, they reported that $F \quad 37.5 \%-44.1 \%$, G $23.2 \%$ $30.9 \%, F+G 63.3 \%-74.8 \%$ and $F / G 1.29-1.78$. Also Can et al. (2015) [20] found the values respectively, F 38.44\%, G 19.35\%, F+G 57.79\%, F/G 1.98\%, at chestnut honey. In our results we found Fructose between $29.20 \%$ and $42.99 \%$, Glucose between $18.25 \%$ and $31.15 \%, F+G$ between $49.18 \%$ and $73.02 \%$ and ratio of $F / G$ between $1.30 \%$ and $1.80 \%$ at chestnut honey samples. It was found Fructose $36.91 \%$ and $37.45 \%$, Glucose $26.52 \%$ and $28.86 \%$, $F+G$ between $63.43 \%$ and $66.30 \%$ and ratio of $F / G$ $1.31 \%$ and $1.38 \%$ at rhododendron honey samples. In our study, it was determined Fructose between $31.03 \%$ and $38.79 \%$, Glucose between $23.26 \%$ and $32.61 \%, \mathrm{~F}+\mathrm{G}$ between $55.99 \%$ and $71.00 \%$ and ratio of $F / G 1.17 \%$ and $1.52 \%$ at chestnut\&rhododendron honey samples (Table 2, Figure 4). Consequently, codex and other studies have been found to be in accordance with our results of sugar analysis.

GC-MS chemical substance analyses of honeys revealed alcohols, aldehydes, ketones, aliphatic acids and their esters, carboxylic acids and their esters and flavonoids (Table 3). Bonago et al. reported that, hydrocarbons ( $n$-Heptacosane, n-nonacosane, $\mathrm{n}$-tricosane, n-pentacosane, and n-hentriacontane, etc), carboxylic acid and esters, were present in the chestnut honeys as a result of the chemical analysis. The same authors reported that in their another studies with unifloral chestnut honey, honeys contained 50 kinds of volatile components [21,22]. In recent years researchers determined furan derivatives in higher amounts in chestnut honey [1,23-25]. Also we found furan derivatives in this study especially in chestnut honey samples $(\mathrm{C} 1, \mathrm{C} 5, \mathrm{C} 6, \mathrm{C} 7, \mathrm{C} 8, \mathrm{C})$.

Radovic et al., (2001) [25] found furfural, which is an aromatic aldehyde, before in acacia honey. It was also determined in lime and lavender honey by Cuevas-Glory et al., (2007) [26]. In this study we

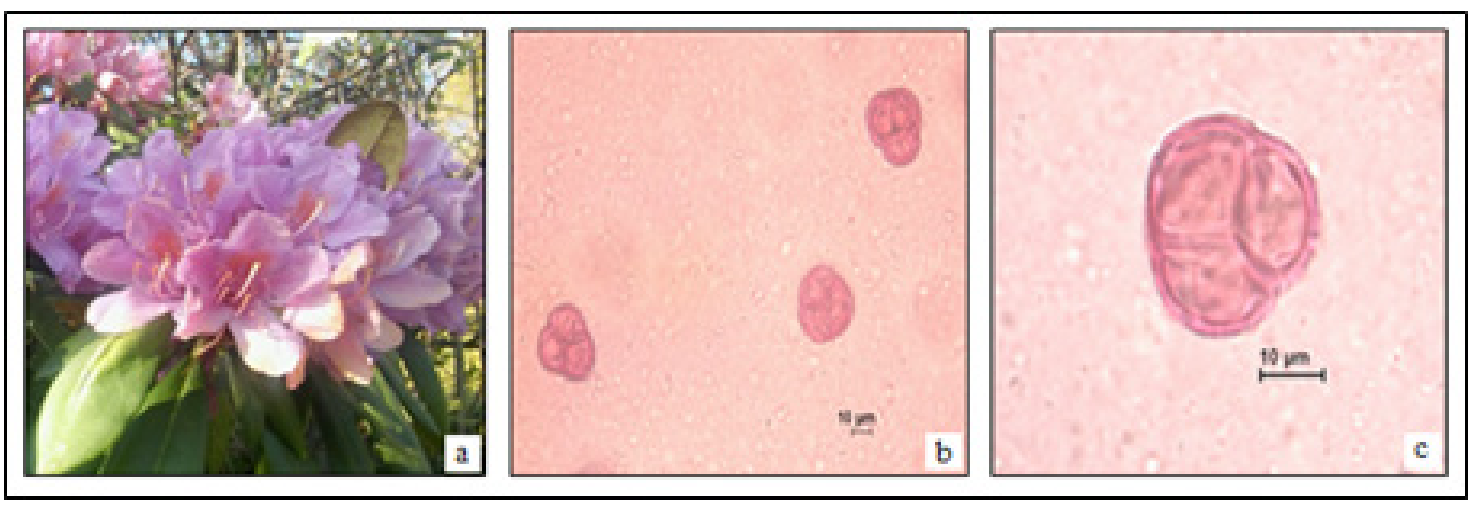

Figure 2. a. Rhododendron ponticum, b-c.pollen photos of Rhododendron spp.
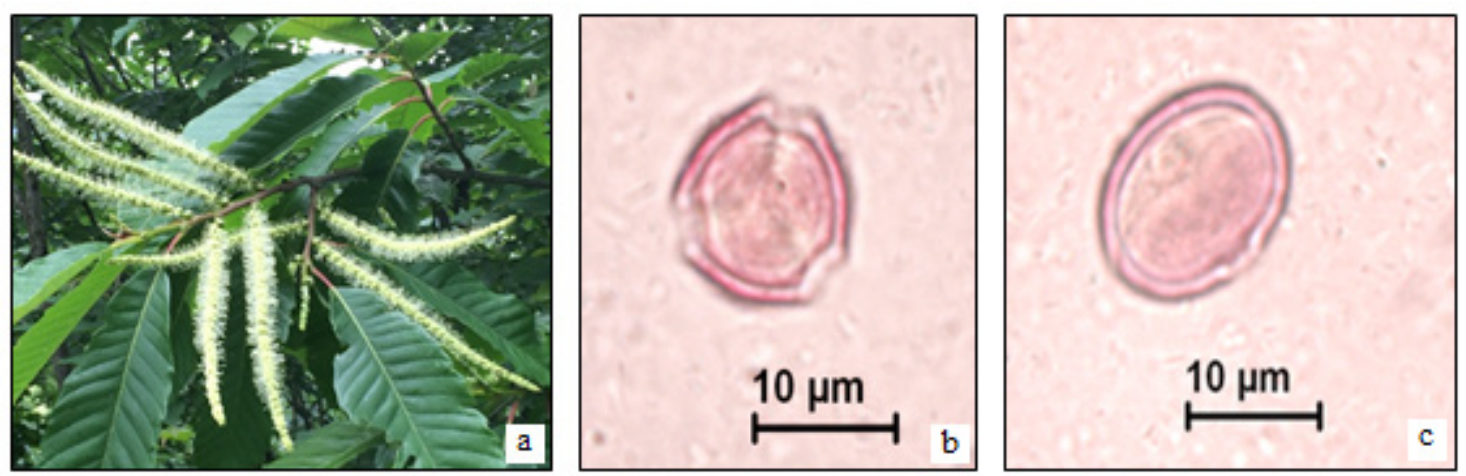

Figure 3. a.Castanea sativa, b-c.polar and equatorial view of Castanea sativa pollen. 
Table 1. Melissopalynologic analysis of honey samples.

\begin{tabular}{|c|c|c|c|c|c|c|c|}
\hline $\begin{array}{l}\text { Honey } \\
\text { sample }\end{array}$ & $\begin{array}{l}\text { Total } \\
\text { Pollen } \\
\text { Number } \\
\text { (TPN) }\end{array}$ & $\begin{array}{l}\text { Predominant } \\
\text { type of pollen } \\
\quad(>45 \%)\end{array}$ & $\begin{array}{l}\text { Secondary } \\
\text { pollen } \\
(15-45 \%)\end{array}$ & $\begin{array}{l}\text { Important } \\
\text { Minor Pollen } \\
(3-15 \%)\end{array}$ & $\begin{array}{l}\text { Minor Pollen } \\
\quad(<3 \%)\end{array}$ & Region & $\begin{array}{l}\text { Honey } \\
\text { type }\end{array}$ \\
\hline 1 & 722419 & $\begin{array}{l}\text { Castanea } \\
\text { sativa } \\
(97.5 \%)\end{array}$ & - & - & $\begin{array}{l}\text { Rumex sp. (1\%) } \\
\text { Rosaceae (1\%) } \\
\text { Fabaceae } \\
(0.5 \%)\end{array}$ & Bartın & Chestnut \\
\hline 2 & 110844 & $\begin{array}{l}\text { Castanea } \\
\text { sativa } \\
(97.7 \%)\end{array}$ & - & - & $\begin{array}{c}\text { Brassicaceae } \\
(1.7 \%) \\
\text { Fabaceae } \\
(0.4 \%)\end{array}$ & Bartın & Chestnut \\
\hline 3 & 511271 & $\begin{array}{l}\text { Castanea } \\
\text { sativa } \\
(97.5 \%)\end{array}$ & - & - & $\begin{array}{c}\text { Rosaceae } \\
\quad(1.5 \%) \\
\text { Asteraceae } \\
\quad(0.5 \%) \\
\text { Rumex sp. } \\
\text { (0.5\%) }\end{array}$ & Bartın & Chestnut \\
\hline 4 & 37626 & $\begin{array}{l}\text { Castanea } \\
\text { sativa } \\
(91.5 \%)\end{array}$ & - & $\begin{array}{c}\text { Ericaceae } \\
(7.42 \%)\end{array}$ & $\begin{array}{c}\text { Asteraceae } \\
(1 \%)\end{array}$ & Bartın & Chestnut \\
\hline 5 & 8733 & $\begin{array}{c}\text { Castanea } \\
\text { sativa } \\
(90 \%)\end{array}$ & - & $\begin{array}{c}\text { Ericaceae } \\
(4.5 \%) \\
\text { Rosaceae } \\
(4.5 \%)\end{array}$ & - & Bartın & Chestnut \\
\hline 6 & 292364 & $\begin{array}{l}\text { Castanea } \\
\text { sativa } \\
(83.7 \%)\end{array}$ & - & $\begin{array}{l}\text { Rosaceae } \\
(8.86 \%)\end{array}$ & $\begin{array}{c}\text { Ericaceae } \\
(2.95 \%) \\
\text { Lamiaceae } \\
(2.46 \%) \\
\text { Cistaceae } \\
(1.97 \%)\end{array}$ & Bartın & Chestnut \\
\hline 7 & 162796 & $\begin{array}{l}\text { Castanea } \\
\text { sativa } \\
(92.5 \%)\end{array}$ & - & - & $\begin{array}{c}\text { Rosaceae (3\%) } \\
\begin{array}{c}\text { Lamiaceae } \\
(2 \%)\end{array} \\
\text { Apiaceae }(1 \%) \\
\text { Cistaceae } \\
(0.5 \%) \\
\text { Chenopodia- } \\
\text { ceae }(0.5 \%) \\
\text { Poaceae } \\
(0.5 \%)\end{array}$ & Bartın & Chestnut \\
\hline
\end{tabular}


140 | N. Mayda et al. / Hacettepe J. Biol. \& Chem., 2018, 46 (1), 135-145

Table 1. Melissopalynologic analysis of honey samples (continue).

\begin{tabular}{|c|c|c|c|c|c|c|c|}
\hline $\begin{array}{l}\text { Honey } \\
\text { sample }\end{array}$ & $\begin{array}{l}\text { Total } \\
\text { Pollen } \\
\text { Number } \\
\text { (TPN) }\end{array}$ & $\begin{array}{l}\text { Predominant } \\
\text { type of pollen } \\
\quad(>45 \%)\end{array}$ & $\begin{array}{l}\text { Secondary } \\
\text { pollen } \\
(15-45 \%)\end{array}$ & $\begin{array}{c}\text { Important } \\
\text { Minor Pollen } \\
(3-15 \%)\end{array}$ & $\begin{array}{c}\text { Minor Pollen } \\
(<3 \%)\end{array}$ & Region & $\begin{array}{l}\text { Honey } \\
\text { type }\end{array}$ \\
\hline
\end{tabular}

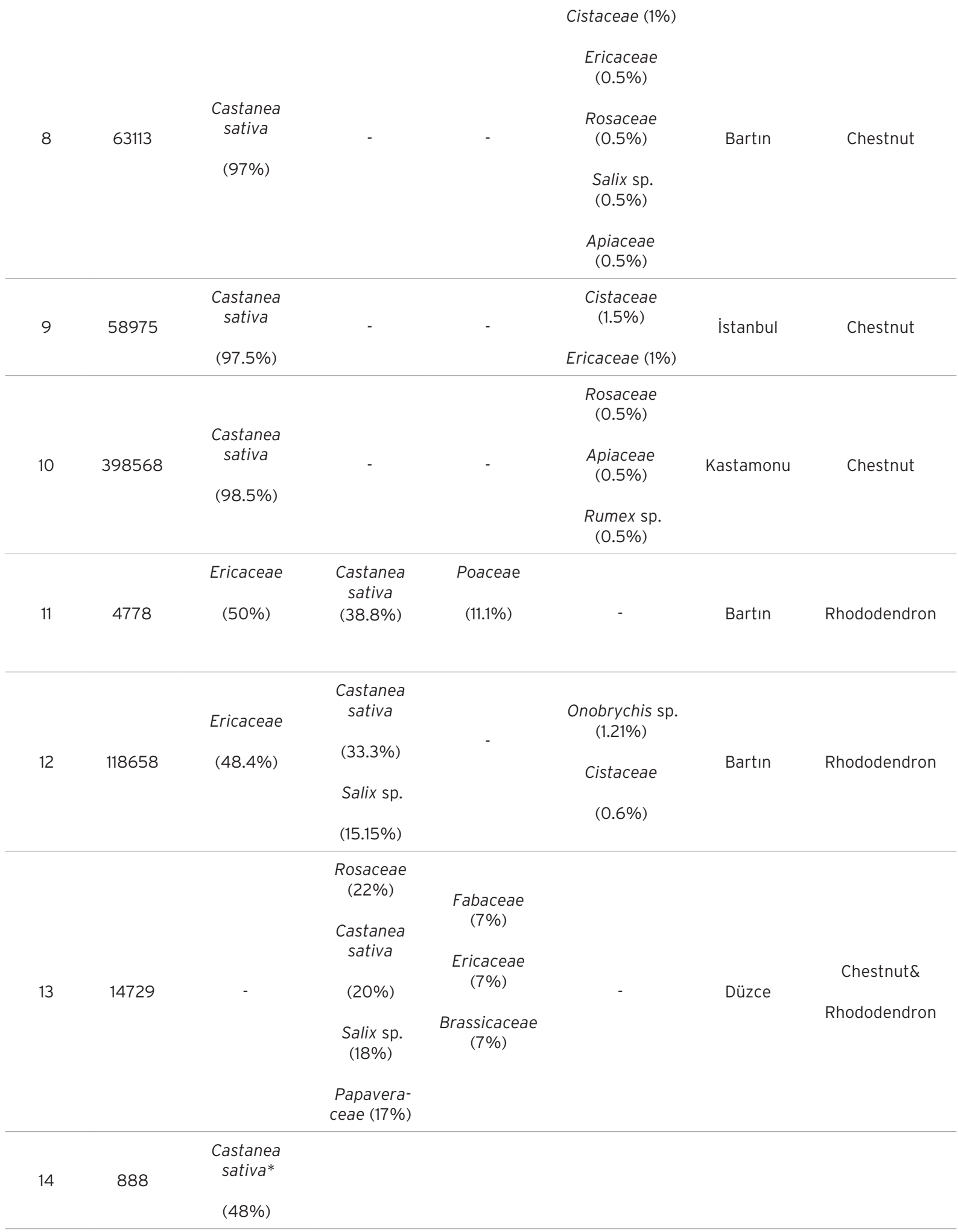


Table 1. Melissopalynologic analysis of honey samples (continue).

\begin{tabular}{|c|c|c|c|c|c|c|c|}
\hline $\begin{array}{l}\text { Honey } \\
\text { sample }\end{array}$ & $\begin{array}{l}\text { Total } \\
\text { Pollen } \\
\text { Number } \\
\text { (TPN) }\end{array}$ & $\begin{array}{l}\text { Predominant } \\
\text { type of pollen } \\
\quad(>45 \%)\end{array}$ & $\begin{array}{c}\text { Secondary } \\
\text { pollen } \\
(15-45 \%)\end{array}$ & $\begin{array}{l}\text { Important } \\
\text { Minor Pollen } \\
(3-15 \%)\end{array}$ & $\begin{array}{c}\text { Minor Pollen } \\
(<3 \%)\end{array}$ & Region & Honey type \\
\hline & & $\begin{array}{c}\text { Castanea } \\
\text { sativa** }\end{array}$ & & $\begin{array}{l}\text { Ericaceae } \\
\quad(14.5)\end{array}$ & Fabaceae (2.8) & & \\
\hline 15 & 76039 & $\begin{array}{l}\text { Sativa* } \\
(68 \%)\end{array}$ & - & $\begin{array}{c}\text { Asteraceae } \\
\text { (9.5) }\end{array}$ & $\begin{array}{l}\text { Rosaceae (2.5) } \\
\text { Apiaceae (2.7) }\end{array}$ & Düzce & $\begin{array}{l}\text { Chestnut\& } \\
\text { Rhododendron }\end{array}$ \\
\hline
\end{tabular}

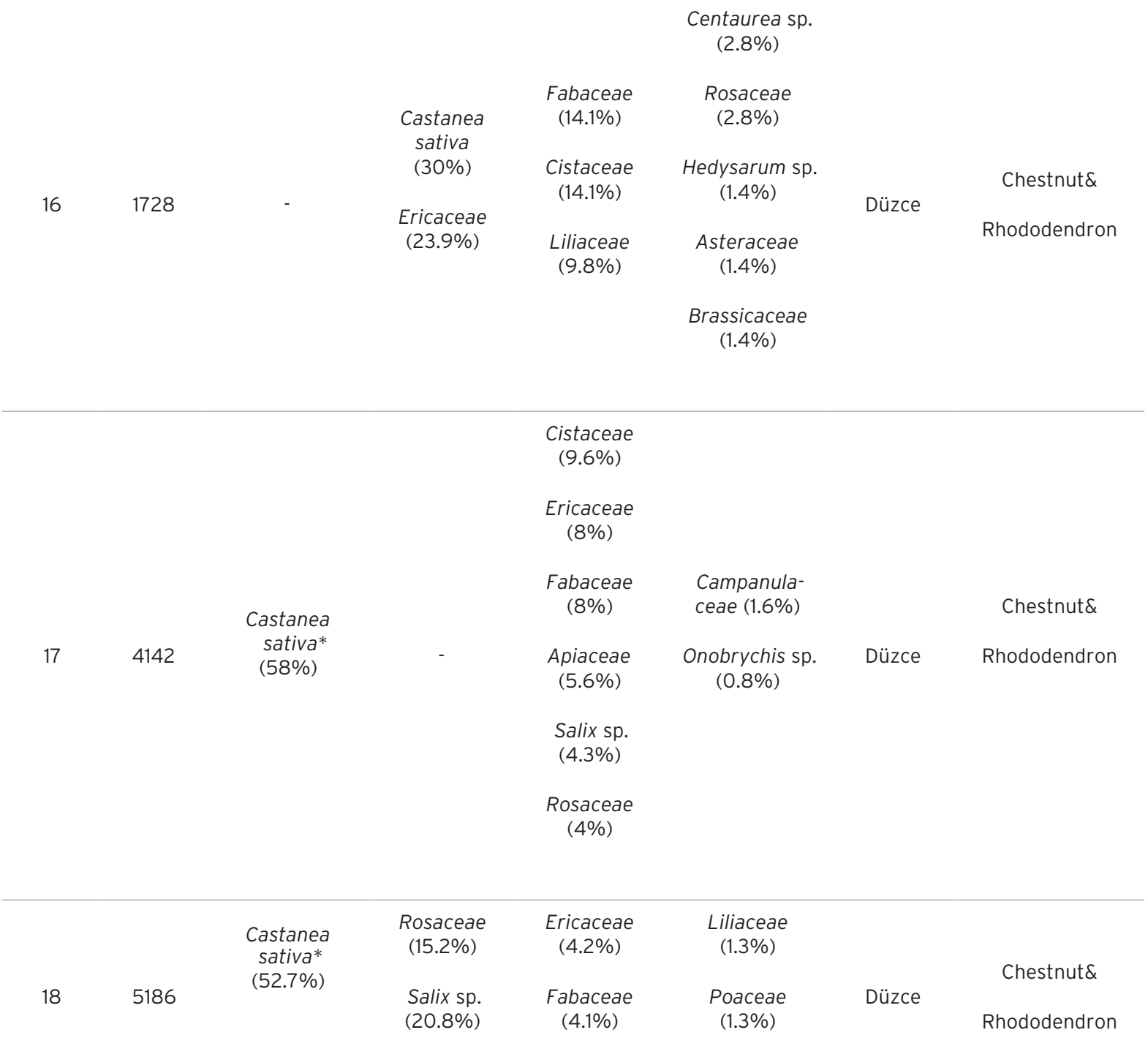

* Chestnut honey, a content of $70-90 \%$ of Castanea pollen is required to classify honey as unifloral. 
Table 2. HPLC sugar analysis results of honey samples.

\begin{tabular}{|c|c|c|c|c|c|}
\hline $\begin{array}{l}\text { Honey } \\
\text { Sample }\end{array}$ & Honey type & Fructose (\%) & Glucose (\%) & $F+G(\%)$ & $F / G(\%)$ \\
\hline $\mathrm{C} 1$ & Chestnut & $33.64 \pm 2.87$ & $19.14 \pm 2.37$ & $52.78 \pm 4.54$ & $1.76 \pm 0.19$ \\
\hline $\mathrm{C} 2$ & Chestnut & $37.81 \pm 2.76$ & $29.12 \pm 5.22$ & $66.96 \pm 7.56$ & $1.30 \pm 0.15$ \\
\hline $\mathrm{C} 3$ & Chestnut & $30.92 \pm 3.95$ & $18.25 \pm 2.63$ & $49.18 \pm 6.36$ & $1.71 \pm 0.09$ \\
\hline $\mathrm{C} 4$ & Chestnut & $29.20 \pm 2.94$ & $24.71 \pm 4.76$ & $53.93 \pm 7.37$ & $1.21 \pm 0.14$ \\
\hline $\mathrm{C} 5$ & Chestnut & $36.68 \pm 0.80$ & $29.52 \pm 3.02$ & $66.20 \pm 3.32$ & $1.24 \pm 0.13$ \\
\hline $\mathrm{C} 6$ & Chestnut & $41.86 \pm 1.33$ & $31.15 \pm 3.72$ & $73.02 \pm 5.04$ & $1.30 \pm 0.12$ \\
\hline $\mathrm{C7}$ & Chestnut & $42.99 \pm 2.20$ & $23.76 \pm 1.77$ & $66.75 \pm 3.68$ & $1.80 \pm 0.09$ \\
\hline $\mathrm{C} 8$ & Chestnut & $40.47 \pm 4.62$ & $25.57 \pm 5.75$ & $66.04 \pm 10.31$ & $1.6 \pm 1.18$ \\
\hline $\mathrm{C9}$ & Chestnut & $33.62 \pm 4.48$ & $23.38 \pm 4.44$ & $57.00 \pm 0.65$ & $1.49 \pm 0.42$ \\
\hline $\mathrm{C} 10$ & Chestnut & $33.04 \pm 3.27$ & $22.90 \pm 3.24$ & $55.94 \pm 4.52$ & $1.46 \pm 0.27$ \\
\hline R11 & Rhododendron & $37.45 \pm 2.05$ & $28.86 \pm 4.22$ & $66.30 \pm 2.53$ & $1.31 \pm 0.25$ \\
\hline $\mathrm{R} 12$ & Rhododendron & $36.91 \pm 5.09$ & $26.52 \pm 1.66$ & $63.43 \pm 5.76$ & $1.38 \pm 0.20$ \\
\hline CR13 & Chestnut\&Rhododendron & $35.41 \pm 0.83$ & $23.26 \pm 0.86$ & $58.67 \pm 1.19$ & $1.52 \pm 0.07$ \\
\hline CR14 & Chestnut\&Rhododendron & $38.39 \pm 3.44$ & $32.61 \pm 1.49$ & $71.00 \pm 4.08$ & $1.17 \pm 0.10$ \\
\hline CR15 & Chestnut\&Rhododendron & $38.79 \pm 1.12$ & $27.62 \pm 1.90$ & $66.41 \pm 1.66$ & $1.40 \pm 0.12$ \\
\hline CR16 & Chestnut\&Rhododendron & $33.23 \pm 0.41$ & $25.00 \pm 0.86$ & $58.23 \pm 1.19$ & $1.32 \pm 0.04$ \\
\hline CR17 & Chestnut\&Rhododendron & $31.56 \pm 1.07$ & $25.13 \pm 0.68$ & $56.7 \pm 1.17$ & $1.25 \pm 0.05$ \\
\hline CR18 & Chestnut\&Rhododendron & $31.03 \pm 0.85$ & $24.96 \pm 1.07$ & $55.99 \pm 1.83$ & $1.24 \pm 0.03$ \\
\hline
\end{tabular}

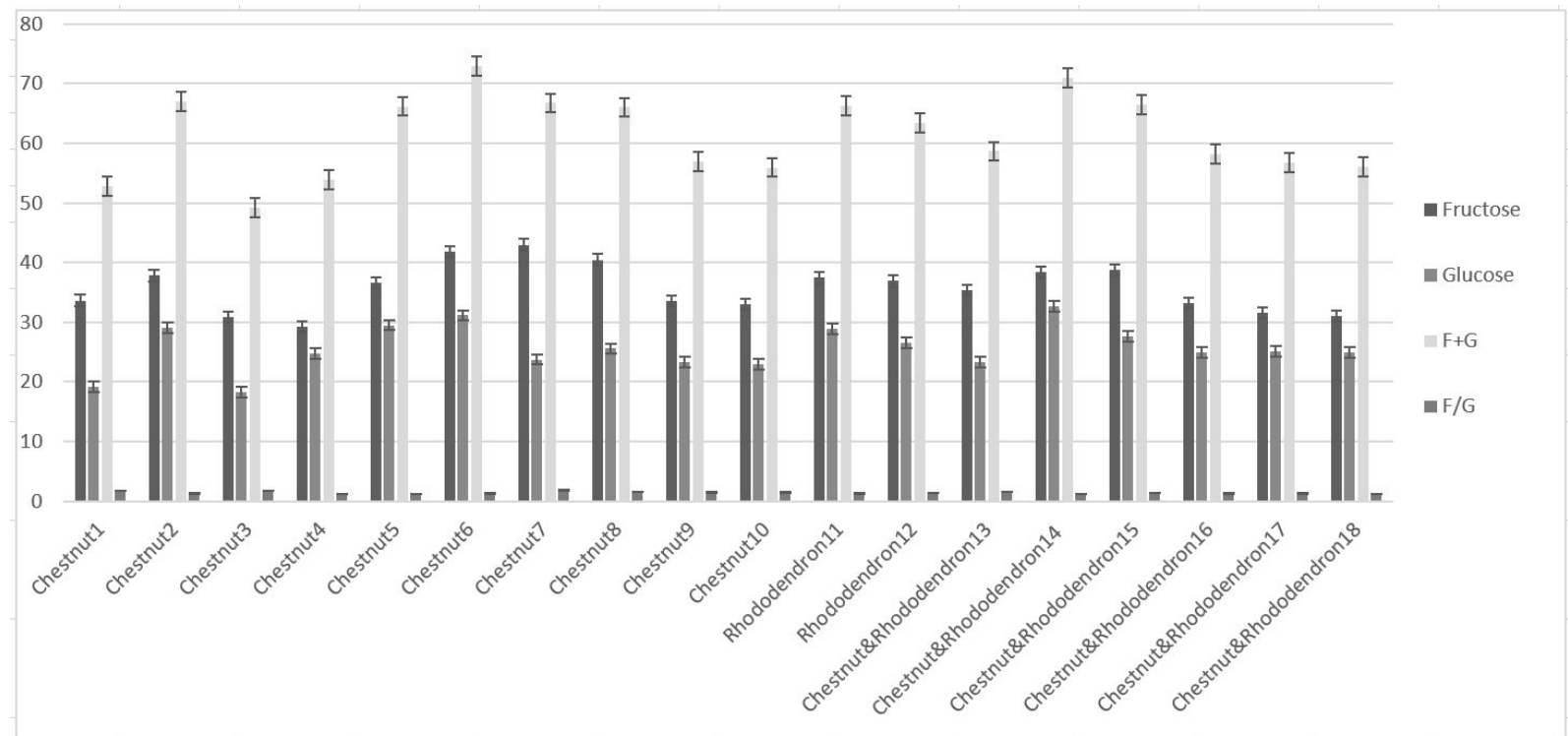

Figure 4. HPLC sugar analysis results of honey samples. 
Table 3. GC-MS analysis results of honey samples.

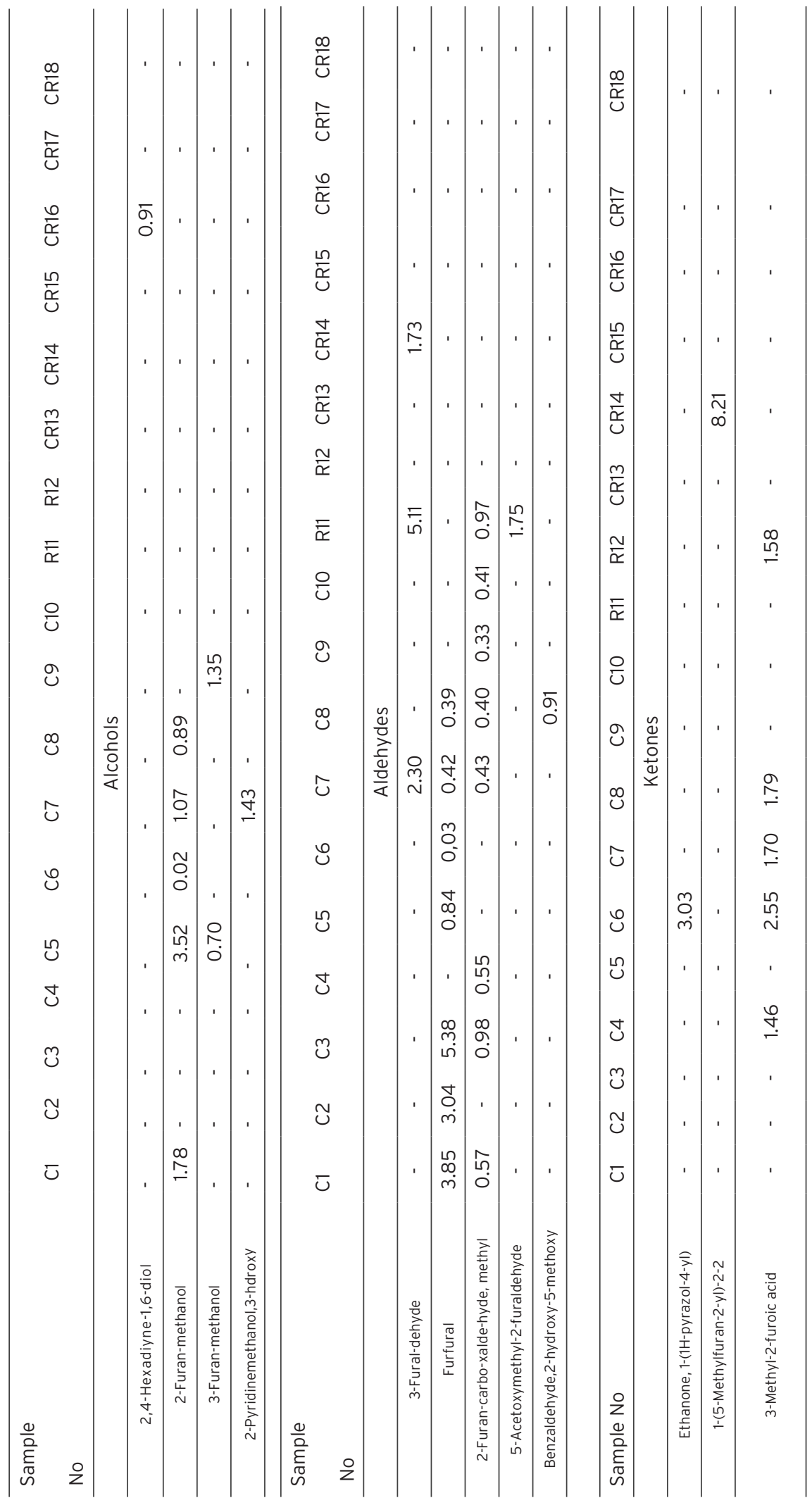


Table 3. GC-MS analysis results of honey samples. (continued)

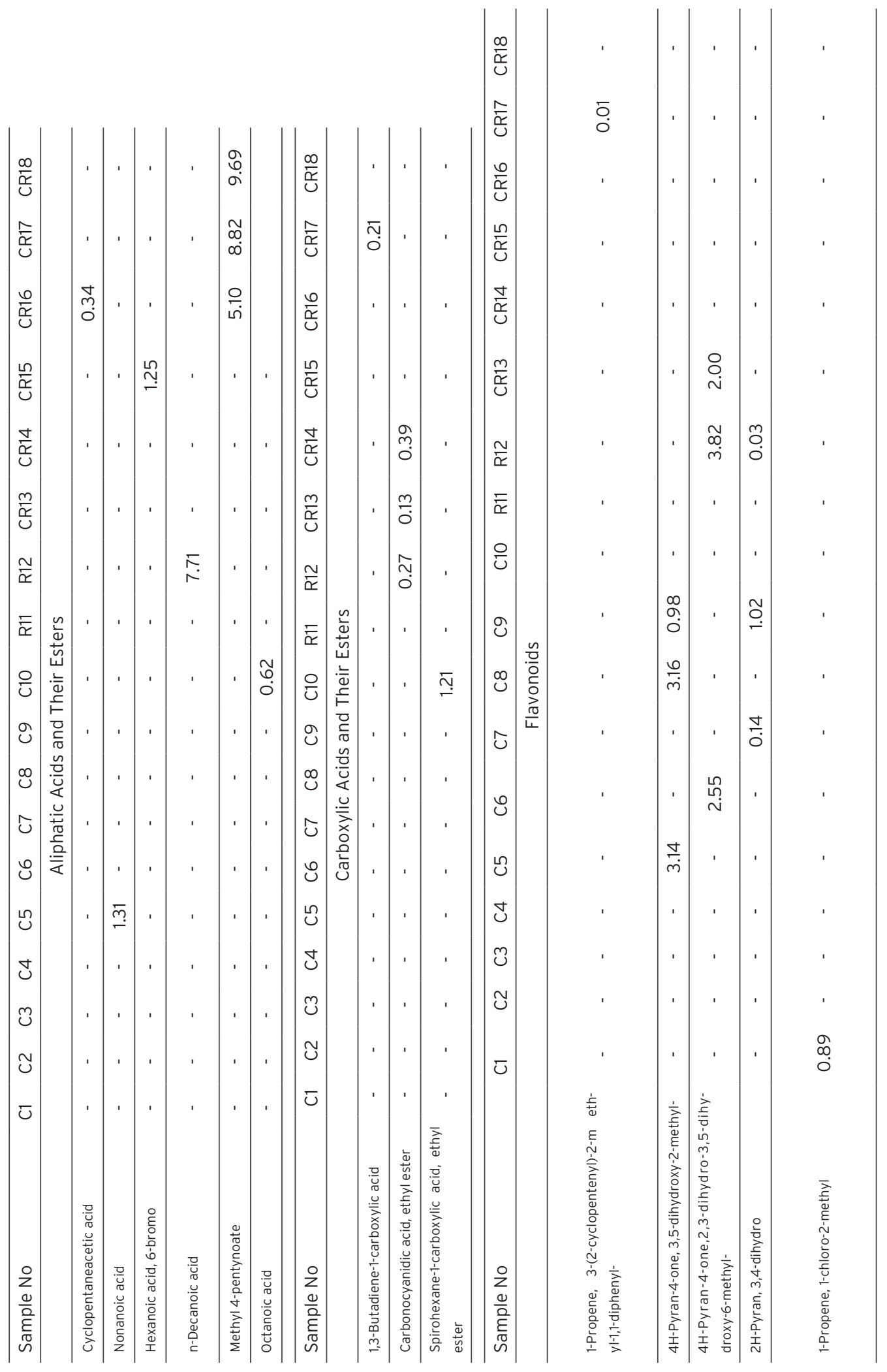


found furfural in seven samples of the ten chestnut honeys (C1,C2,C3,C5,C6,C7,C8) (Table 3).

Flavanoids are important compounds because of their antioxidant effects. Flavanones are one of the most important groups of the flavonoids. Yu et al., 2013 and Özkök et al., 2016 [27,28] determined 2,3-dihydro-3,5-dihydroxy-6-methyl-4H-pyran-4one (DDMP) flavanones which is a strong antioxidant in the pine honey samples. Also we found DDMP in the C6, R12 and CR13 samples (Table 3).

In this study, the chemical composition of chestnut and rhododendron honeys and their sugar content were investigated and it was determined that they could show changes depending on the botanical origins of honey.

\section{ACKNOWLEDGEMENTS}

We would like to thank Turkish Association of Beekeepers (TAB) and beekeepers who helped us for providing samples during our fieldwork.

\section{References}

1. E. Alissandrakis, P.A. Tarantilis, C. Pappas, P.C. Harizanis, M. Polissiou, Investigation of organic extractives from unifloral chestnut (Castanea sativa L.) and eucalyptus (Eucalyptus globulus Labill.) honeys and flowers to identification of botanical marker compounds, LWT-Food Sci. Tech., 44 (2011) 1042-1051.

2. S. Silici, A.T. Atayoglu, Mad honey intoxication: a systematic review on the 1199 cases, Food Chem. Toxic., 86 (2015) 282-290.

3. P. Stevens, Rhododendron L. Flora of Turkey and the East Aegean Islands, 6 (1978) 90-94.

4. Y. Qiang, B. Zhou, K. Gao, Chemical constituents of plants from the genus Rhododendron, Chem. \& Biod., 8 (2011) 792-815.

5. K.F. Lampe, Rhododendrons, mountain laurel, and mad honey, Jama, 259 (1988) 2009-2009.

6. S. Cestèle, W.A. Catterall, Molecular mechanisms of neurotoxin action on voltage-gated sodium channels, Biochimie, 82 (2000) 883-892.

7. T. Narahashi, I. Seyama, Mechanism of nerve membrane depolarization caused by grayanotoxin I. J. Phys., 242,2 (1974) 471-487.

8. R.P. Wodehouse, Pollen grains: Mcgraw-Hill Book Company, Inc; New York; London, 1935.

9. K. Sorkun, Türkiye'nin Nektarlı Bitkileri, Polenleri ve Balları: Palme Yayıncılık, Türkiye, 2008.
10. L.P. Oddo, R. Piro, É. Bruneau, C. Guyot-Declerck, T. Ivanov, J. Piskulová, H. Russmann, Main European unifloral honeys: descriptive sheets, Apidologie, 35 (2004) S38-S81.

11. A.Ö. Tüylü, K. Sorkun, The investigation of morphologic analysis of pollen grains which are economically important and collected by Apis mellifera L., Hacettepe J. Bio. Chem., 35 (2007) 31-38.

12. F. Corvucci, L. Nobili, D. Melucci, F.V. Grillenzoni, The discrimination of honey origin using melissopalynology and Raman spectroscopy techniques coupled with multivariate analysis, Food Chem., 169 (2015) 297-304.

13. A.G.Sabatini, L. Bortolotti, G.L. Marcazzan, Conoscere il miele: Avenue media, 2007.

14. A. Terrab, A.G. González, M.J. Díez, F.J. Heredia, Characterisation of Moroccan unifloral honeys using multivariate analysis, European Food Res. Tech., 218 (2003) 88-95.

15. S. Bogdanov, E. Baumann, Bestimmung von Honigzucker mit HPLC, Mitt Geb Lebensmittelunters Hyg, 79 (1988) 198-206.

16. Türk Gıda Kodeksi Bal Tebliği, 2012/58 C.F.R. (2012).

17. Codex Standard12. Revised Codex Standard for Honey, Standards and Standard Methods, 11 C.F.R. 2001.

18. J.W. White Jr, Honey., In Advances in food research, 24 (1978), 287-374.

19. A.B. Manzanares, Z.H. García, B.R. Galdón, E.M. Rodríguez-Rodríguez, C.D. Romero, Physicochemical characteristics and pollen spectrum of monofloral honeys from Tenerife, Spain, Food Chem., 228 (2017) 441-446.

20. Z. Can, O. Yildiz, H. Sahin, E.A. Turumtay, S. Silici, S. Kolayli, An investigation of Turkish honeys: their physico-chemical properties, antioxidant capacities and phenolic profiles, Food Chem., 180 (2015) 133-141.

21. G. Bonaga, A.G. Giumanini, The volatile fraction of chestnut honey. J. Api. Res., 25 (1986) 113-120.

22. G. Bonaga, A.G. Giumanini, G. Gliozzi, Chemical composition of chestnut honey: analysis of the hydrocarbon fraction J. Agricult. Food Chem., 34 (1986) 319-326.

23. A. Bouseta, S. Collin, J.P. Dufour, Characteristic aroma profiles of unifloral honeys obtained with a dynamic headspace GC-MS system, J. Api. Res., 31 (1992) 96-109.

24. C. Guyot, A. Bouseta, V. Scheirman, S. Collin, Floral origin markers of chestnut and lime tree honeys, J. Agricult. Food Chem., 46 (1998) 625-633.

25. B. Radovic, M. Careri, A. Mangia, M. Musci, M. Gerboles, E. Anklam, Contribution of dynamic headspace GC-MS analysis of aroma compounds to authenticity testing of honey, Food Chem., 72 511-520.

26. L.F. Cuevas-Glory, J.A. Pino, L.S. Santiago, E. SauriDuch, A review of volatile analytical methods for determining the botanical origin of honey, Food Chem., 103 (2007) 1032-1043.

27. X. Yu, M. Zhao, F. Liu, S. Zeng, J. Hu, Identification of 2,3-dihydro-3,5-dihydroxy-6-methyl-4H-pyran-4-one as a strong antioxidant in glucose-histidine Maillard reaction products, Food Res. Int., 51 (2013) 397-403. 